\section{Подяка редакційній колегії, виробничому колективу, рецензентам та авторам за роботу для «Праці Наукового Товариства ім. Шевченка. Медичні науки» у 2020 р.}

\author{
Оксана Заячківська ${ }^{1}$, Марта Ковальська² \\ ${ }^{1}$ Головний редактор, журнал «Праці Наукового Товариства \\ ім. Шевченка. Медичні науки» \\ ${ }^{2}$ Асистент редактора, журнал «Праці Наукового Товариства \\ ім. Шевченка. Медичні науки»
}

Висловлюємо вдячність колегам з цьогорічного й минулорічного редакторського та виробничого колективів, авторам і рецензентам нашого журналу за співпрацю у 2020 р. Hезважаючи на виклики, спричинені COVID-19, наш журнал нещодавно прийнято до Directory of Open Access Journals (DOAJ), а процес його включення до каталогу періодичних видань Ulrichsweb \& Ulrichs на завершенні. Як і всі міжнародні рецензовані журнали з відкритим доступом, редакція журналу «Праці Наукового Товариства ім. Шевченка. Медичні науки» отримує рукописи зі всього світу [1-7]. Рішення про публікацію ґрунтується на важливості та ймовірній цікавості змісту статті для українських та інших медичних працівників і науковців, а також успішному критичному рецензуванні запрошеними експертами [8-10].

У 2020 р. редакційна колегія «Праці Наукового Товариства ім. Шевченка. Медичні науки» доклала багато зусиль для вдосконалення засад рецензування у нашому журналі, провівши серію регулярних освітніх курсів / вебінарів для підвищення редакційних компетентностей у покращенні якості наукових публікацій для читачів журналу.

Вся редакція «Праці Наукового Товариства ім. Шевченка. Медичні науки» щиро вдячна авторам за цікаві публікації. Серед них найкращими авторами (на основі кількості завантажень їхніх статей та позитивних відгуків у соціальних мережах) $€$ д-р Шандор Сабо (Американський університет охорони здоров'я, Каліфорнія, США) та д-р Наталія Матолінець (Львівський національний медичний університет імені Данила Галицького, Львів, Україна).

До співпраці у журналі «Праці Наукового Товариства Шевченка. Медична науки» запрошено нових членів редакції та рецензентів для експертної перевірки рукописів у 2020 р. Висловлюємо щиру вдячність за волонтерську роботу усім членам редакційної колегії, виробничої команди та рецензентам, яких зазначаємо нижче. Нашими топ-рецензентами 2020 р. $€$ д-р Андрій Черкас (Sanofi-Aventis-Німеччина, Франкфурт-на-Майні, Німеччина), д-р Неля Орищишин (Львівський національний медичний університет імені Данила Галицького, Львів, Україна), д-р Василь Лончина (Чиказький університет медицини Притцкера Чикаго, США). 


\section{OPEN ӘaCcess}

DOI: $10.25040 /$ ntsh2020.02.15

For correspondence:

Pekarska st, 69, Lviv, Ukraine, 79010

Е-пошта: ozayachkivska@gmail.com

Received: Sep, 1, 2020

Accepted: Sep, 10, 2020

Published online: Sep, 29, 2020

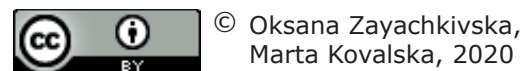

\section{ORCID IDs}

Oksana Zayachkivska

https://orcid.org/0000-0002-4309-2473 Marta Kovalska

https://orcid.org/0000-0002-6232-3951

AUTHOR CONTRIBUTIONS: All authors contributed equally to the first draft of the manuscript, manuscript revision, and read and approved the submitted version. OZ and MK share first authorship of this publication.

\title{
Appreciation to the editorial boards, production teams, reviewers and authors for the Proceeding of the Shevchenko Scientific Society. Medical Sciences in $\mathbf{2 0 2 0}$
}

\author{
Oksana Zayachkivska ${ }^{1}$, Marta Kovalska² \\ ${ }^{1}$ Editor-in-Chief, The Proceedings of Shevchenko Scientific \\ Society. Medical Sciences \\ ${ }^{2}$ Assistant Editor, The Proceedings of Shevchenko Scientific \\ Society. Medical Sciences
}

We would like to thank our past and present editorial and production teams and our authors for cooperation in 2020. Despite of COVID-19 challenges in 2020, our journal has recently received acceptations to the Directory of Open Access Journals (DOAJ) and in processing to Ulrichsweb \& Ulrichs Periodicals Directory. The Proceedings of Shevchenko Scientific Society. Medical Sciences obtains manuscripts over the world [1-8]. The decision on their publications is based on potentially influential contents of interest to Ukrainian and other medical and healthcare professionals, scientists and medical students after successful critical peer review [9]. All of the editorial staff of The Proceedings of Shevchenko Scientific Society. Medical Sciences sincerely appreciates the authors' contributions. Among them, the best corresponding authors (based on download counts of their articles and positive social media attention) are Dr. Sandor Szabo (American University Health Science, CA, USA) and Dr. Natalia Matolinets (Danylo Halytsky Lviv National Medical University, Lviv, Ukraine).

In 2020, The Proceedings of Shevchenko Scientific Society. Medical Sciences has put all efforts to upgrade the Journal peer review standards, offering regular educational courses/webinars to advance their editorial credentials to better serve the professional interests of the Journal readers.

The Proceedings of Shevchenko Scientific Society. Medical Sciences invited new editorial board members and experts for peer review of the manuscripts in 2020, and some of them received multiple invitations. We honestly appreciate the voluntary contribution of all of the members of the editorial team, executive, and editorial boards of PSSS MS and all reviewers as introduced below. Among reviewers, top peer reviewers (based on their contribution of 4 or more reviews) are Dr. Andriy Cherkas (Sanofi-Aventis-Deutschland GmbH - Industriepark Höchst, Frankfurt am Main, Germany), Dr. Nelia Oryshchyn (Danylo Halytsky Lviv National Medical University, Lviv, Ukraine), Dr. Vassyl Lonchyna (University of Chicago Pritzker School of Medicine, Chicago, United States).

Cite this article as: Appreciation to the editorial boards, production teams, reviewers and authors for the Proceeding of the Shevchenko Scientific Society. Medical Sciences in 2020. Proc Shevchenko Sci Soc Med Sci. 2020; 62(2):15-22. 


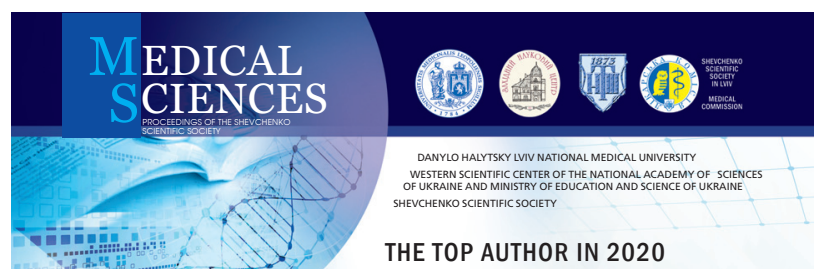

Proceedings of the Shevchenko Scientific Society. Medical Sciences AWARDED TO

DR. NATALIA MATOLINETS
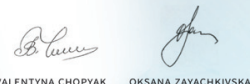

VALENTWA CHOPYAK OKSANA ZaAACHKINSKA

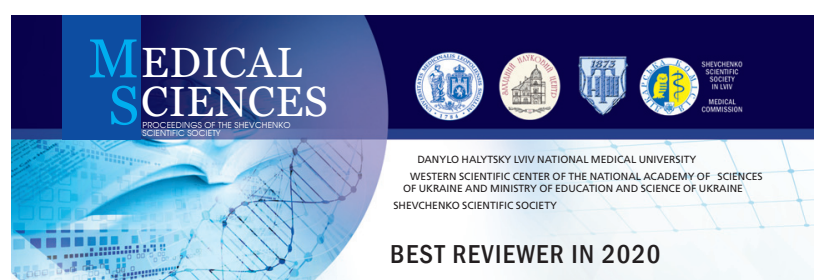

Proceedings of the Shevchenko Scientific Society. Medical Sciences AWARDED TO

DR. ANDRIY CHERKAS

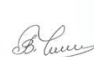

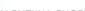

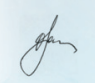

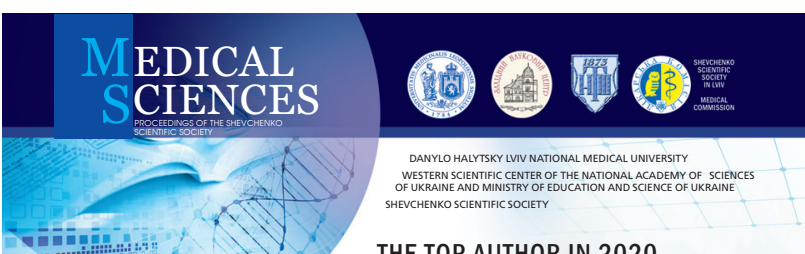

THE TOP AUTHOR IN 2020

Proceedings of the Shevchenko Scientific Society. Medical Sciences

AWARDED TO

DR. SANDOR SZABO
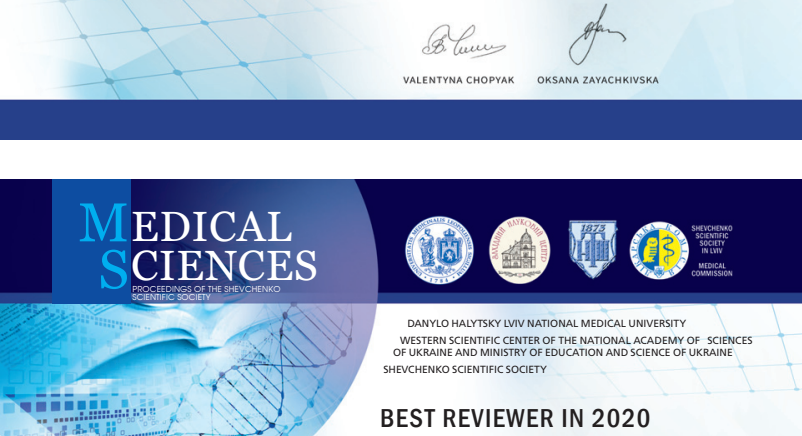

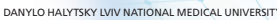

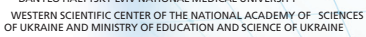

\section{BEST REVIEWER IN 2020}

Proceedings of the Shevchenko Scientific Society. Medical Sciences AWARDED TO

DR. VASSYL LONCHYNA
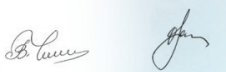

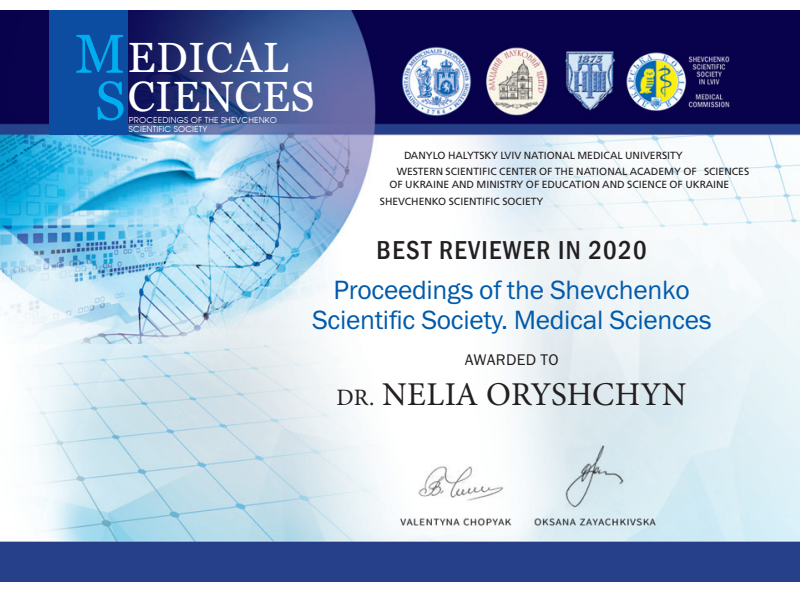


Праці НТШ Медичні науки

2020, Том 62, № 2 ISSN 2708-8634 (print)

Від редактора

\section{Aleksander Lutsyk}

Danylo Halytsky Lviv National Medical University Lviv, Ukraine

Andrew Ripecky

U.S. Department of Veterans Affairs Chicago, Illinois, USA

Andrew Vergun

Danylo Halytsky Lviv National Medical University Lviv, Ukraine

Andrew W. Browar

Midwestern University College of Dental Medicine-IL Downers Grove

Andrey V. Cybulsky

Centre universitaire de santé McGill

Montreal, Canada

Andrij Gnatush

Ivan Franko National University of Lviv, Lviv, Ukraine

Andrij Netljuh

Danylo Halytsky Lviv National Medical University Lviv, Ukraine

Andriy Bazylevych

Danylo Halytsky Lviv National Medical University Lviv, Ukraine

\section{Andriy Cherkas}

Sanofi-Aventis-Deutschland $\mathrm{GmbH}$ - Industriepark Höchst, Frankfurt am Main, Germany

\section{Anton Coenen}

Radboud University Nijmegen

Nijmegen, Netherlands

Antonina Yashhenko

Danylo Halytsky Lviv National Medical University Lviv, Ukraine

Bohdana Doskaliuk

Ivano-Frankivsk National Medical University< Ivano-Frankivsk, Lviv, Ukraine

\section{Borys Bilynsky}

Danylo Halytsky Lviv National Medical University Lviv, Ukraine

Borys Zimenkovsky

Danylo Halytsky Lviv National Medical University Lviv, Ukraine

Christine Lishchuk-Yakymovych

Danylo Halytsky Lviv National Medical University Lviv, Ukraine

Khrystyna Stus

Danylo Halytsky Lviv National Medical University Lviv, Ukraine

Khrystyna Dzhyoieva

Danylo Halytsky Lviv National Medical University Lviv, Ukraine
Proc Shevchenko Sci Soc Med Sci www.mspsss.org.ua ISSN 2708-8642 (online) 2020, Vol. 62,

\section{Олександр Луцик}

Львівський національний медичний університет імені Данила Галицького, м.Львів, Україна

\section{Андрій Ріпецький}

Міністерство у справах ветеранів США м.Чикаго, штат Іллінойс, США

\section{Андрій Вергун}

Львівський національний медичний університет імені Данила Галицького, м.Львів, Україна

Андрій Бровар

Midwestern University College of Dental Medicine-IL м.Дауннерс Гай

Андрій цибульський

Центр університету Сант Макгілл м.Монреаль, Канада

Андрій Гнатиш

Львівський національний університет імені Івана Франка, м.Львів, Україна

\section{Андрій Нетлюх}

Львівський національний медичний університет імені Данила Галицького, м.Львів, Україна

\section{Андрій Базилевич}

Львівський національний медичний університет імені Данила Галицького, м.Львів, Україна

\section{Андрій Черкас}

Фармацевтична компанія Sanofi-AventisНімеччина м.Франкфурт-на-Майні, Німеччина

\section{Антон Коенен}

Університет Радбуда, Неймеген м.Неймеген, Нідерланди

\section{Антоніна Ященко}

Львівський національний медичний університет імені Данила Галицького, м.Львів, Україна

Богдана Доскалюк

Івано-Франківський національний медичний університет, м.Івано-Франківськ, Україна

\section{Борис Білинський}

Львівський національний медичний університет імені Данила Галицького, м.Львів, Україна

\section{Борис Зіменковський}

(Львівський національний медичний університет імені Данила Галицького, Львів, Україна)

\section{Христина Ліщук-Якимович}

Львівський національний медичний університет імені Данила Галицького, м.Львів, Україна

\section{Христина Стус}

Львівський національний медичний університет імені Данила Галицького, м.Львів, Україна

\section{Христина Джиоєва}

Львівський національний медичний університет імені Данила Галицького, м.Львів, Україна 


\section{Darij Bidjuk}

Danylo Halytsky Lviv National Medical University Lviv, Ukraine

\section{Dmytro Telishevsky}

Danylo Halytsky Lviv National Medical University Lviv, Ukraine

\section{George Jaskiw}

Case Western Reserve University, Cleveland United States

\section{Ihor Trutyak}

Danylo Halytsky Lviv National Medical University Lviv, Ukraine

Ines Drenjancevic

Josip Juraj Strossmayer University of Osijek Osijek, Croatia

\section{Iryna Kovalchuk}

Danylo Halytsky Lviv National Medical University Lviv, Ukraine

Ivan Dzis

Danylo Halytsky Lviv National Medical University Lviv, Ukraine

Ivan Gout

UCL London, United Kingdom

Jarema Kaminsky

Danylo Halytsky Lviv National Medical University Lviv, Ukraine

John Wallace

University of Calgary, Calgary, Canada

\section{Julian Mycyk}

Danylo Halytsky Lviv National Medical University Lviv, Ukraine

Julia Kuzyk

Danylo Halytsky Lviv National Medical University Lviv, Ukraine

\section{Julia Khomych}

Ivan Franko National University of Lviv, Lviv, Ukraine

\section{Lesja Kobylins'ka}

Danylo Halytsky Lviv National Medical University Lviv, Ukraine

Lesya Mateshuk-Vatseba

Danylo Halytsky Lviv National Medical University Lviv, Ukraine

Marta Kovalska

Danylo Halytsky Lviv National Medical University Lviv, Ukraine

Maryana Savytska

Danylo Halytsky Lviv National Medical University Lviv, Ukraine

\section{Дарій Бідюк}

Львівський національний медичний університет імені Данила Галицького, м.Львів, Україна

\section{Дмитро Телішевський}

Львівський національний медичний університет імені Данила Галицького, м.Львів, Україна

\section{Джордж Ясків}

Університет Case Western Reserve, м.Клівленд, Сполучені Штати

\section{Ігор Трутяк}

Львівський національний медичний університет імені Данила Галицького, м.Львів, Україна

\section{Інес Дреньянчевич}

Університет Йосипа Юрая Штросмаєра в Осієку м.Осієк, Хорватія

\section{Ірина Ковальчук}

Львівський національний медичний університет імені Данила Галицького, м.Львів, Україна

\section{Іван Дзісь}

Львівський національний медичний університет імені Данила Галицького, м.Львів, Україна

\section{Іван Гот}

UCL м.Лондон, Об'єднане Королівство

\section{Ярема Камінський}

Львівський національний медичний університет імені Данила Галицького, м.Львів, Україна

\section{Джон Валацце}

Університет в Калгарі

м.Калгарі, Канада

юліан Мицик

Львівський національний медичний університет імені Данила Галицького, м.Львів, Україна

\section{Юлія Кузик}

Львівський національний медичний університет імені Данила Галицького, м.Львів, Україна

\section{Юлія Хомич}

Львівський національний університет імені Івана Франка, м.Львів, Україна

\section{Леся Кобилінська}

Львівський національний медичний університет імені Данила Галицького, м.Львів, Україна

\section{Леся Матешук-Вацеба}

Львівський національний медичний університет імені Данила Галицького, м.Львів, Україна

\section{Марта Ковальська}

Львівський національний медичний університет імені Данила Галицького, м.Львів, Україна

\section{Мар'яна Савицька}

Львівський національний медичний університет імені Данила Галицького, м.Львів, Україна 
Michael Yaremchuk

Harvard Medical School

Boston, United States

Myron Ivan Cybulsky

Toronto General Research Institute University of Toronto, Toronto, Canada

Natalia Volodko

Danylo Halytsky Lviv National Medical University Lviv, Ukraine

Natalija Kushnir

Danylo Halytsky Lviv National Medical University Lviv, Ukraine

Natalija Matolinets

Danylo Halytsky Lviv National Medical University Lviv, Ukraine

Nathalie Vergnolle

IRSD, Université de Toulouse

Toulouse France

\section{Natalia Zaichko}

National Pirogov Memorial Medical University, Vinnytsya, Ukraine

Nataliya Vynograd

Danylo Halytsky Lviv National Medical University Lviv, Ukraine

\section{Natalia Plusa}

Danylo Halytsky Lviv National Medical University Lviv, Ukraine

Nelja Oryshhyshyn

Danylo Halytsky Lviv National Medical University Lviv, Ukraine

Nazar Bula

Lviv Regional Clinical Hospital Lviv, Ukraine

\section{Oksana Macjura}

Danylo Halytsky Lviv National Medical University Lviv, Ukraine

Oksana Sulaieva

Medical Laboratory CSD Kyiv, Ukraine

Oleg Danylyak

Danylo Halytsky Lviv National Medical University Lviv, Ukraine

Oleh Antonyshyn

Sunnybrook Health Science Centre Toronto, Canada

Oleksandr Babliak

Cardiac surgery center MM Dobrobut Kyiv, Ukraine

Oleksandr Kitsera

Danylo Halytsky Lviv National Medical University Lviv, Ukraine
Михайло Яремчук

Гарвардська медична школа

м.Бостон, США

Мирон Іван Цибульський

Інститут загальних досліджень Торонто м.Торонто, Канада

Наталія Володько

Львівський національний медичний університет імені Данила Галицького, м.Львів, Україна

\section{Наталія Кушнір}

Львівський національний медичний університет імені Данила Галицького, м.Львів, Україна

Наталія Матолінець

Львівський національний медичний університет імені Данила Галицького, м.Львів, Україна

\section{Наталія Вергноле}

IRSD, Тулузький університет

м.Тулуза, Франція

\section{Наталя Заічко}

Вінницький національний медичний університет ім. Пирогова, м.Вінниця, Україна

\section{Наталя Виноград}

Львівський національний медичний університет імені Данила Галицького, м.Львів, Україна

\section{Наталія Плиса}

Львівський національний медичний університет імені Данила Галицького, м.Львів, Україна

\section{Неля Орищишин}

Львівський національний медичний університет імені Данила Галицького, м.Львів, Україна

\section{Назар Була}

Львівська обласна клінічна лікарня м.Львів, Україна

\section{Оксана Мацюра}

Львівський національний медичний університет імені Данила Галицького, м.Львів, Україна

Оксана Сулаєва

Медична лабораторія "ЦСД" м.Київ, Україна

\section{Олег Даниляк}

Львівський національний медичний університет імені Данила Галицького, м.Львів, Україна

\section{Олег Антонишин}

Науковий центр здоров'я Санібрука

м.Торонто, Канада

Олександр Бабляк

Лікувально-діагностичний центер "Добробут" м.Київ, Україна

Олександр Кітцера

Львівський національний медичний університет імені Данила Галицького, м.Львів, Україна 
Oleksandr Shchur

Danylo Halytsky Lviv National Medical University Lviv, Ukraine

\section{Oleksandr Zavadka}

Danylo Halytsky Lviv National Medical University Lviv, Ukraine

Olena Gavrilyuk

Danylo Halytsky Lviv National Medical University Lviv, Ukraine

\section{Olena Zimba}

Danylo Halytsky Lviv National Medical University Lviv, Ukraine

Olesja Godovana

Danylo Halytsky Lviv National Medical University Lviv, Ukraine

Olesja Kihtjak

Danylo Halytsky Lviv National Medical University Lviv, Ukraine

Olha Kukhlenko (Melekh)

Otto-von-Guericke- Universitat Magdeburg

Magdeburg, Dieutschland

Orest Chevtchik

Medizinische Universitat Innsbruck

Innsbruck, Austria

Oxana Volod

Cedars-Sinai Medical Center

Los Angeles, CA, USA

\section{Pavlo Sodomora}

Danylo Halytsky Lviv National Medical University Lviv, Ukraine

Roman Gladyshevskii

Ivan Franko National University of Lviv Lviv, Ukraine

Roman Kushnir

Chairman of Shevchenko Scientific Society Lviv, Ukraine

Ronnie Fass

Metro Health Medical Center Cleveland Cleveland, United States

\section{Rostyslav Bilyy}

Danylo Halytsky Lviv National Medical University Lviv, Ukraine

\section{Rostyslav Stoika}

Institute of Cell Biology National Academy of Sciences of Ukraine, Lviv, Ukraine

Sandor Szabo

American University of Health Sciences CA, USA

\section{Sergiy Pasichnyk}

Danylo Halytsky Lviv National Medical University Lviv, Ukraine

\section{Олександр Щур}

Львівський національний медичний університет імені Данила Галицького, м.Львів, Україна

\section{олександр Завадка}

Львівський національний медичний університет імені Данила Галицького, м.Львів, Україна

\section{Олена Гаврилюк}

Львівський національний медичний університет імені Данила Галицького, м.Львів, Україна

\section{Олена Зімба}

Львівський національний медичний університет імені Данила Галицького, м.Львів, Україна

\section{Олеся Годована}

Львівський національний медичний університет імені Данила Галицького, м.Львів, Україна

\section{Олеся Кіхтяк}

Львівський національний медичний університет імені Данила Галицького, м.Львів, Україна

Ольга Кухленко (Мелех)

Отто-фон-Геріке - Університет Магдебурга м.Магдебург, Німеччина

Орест Шевчик

Медичний університет Інсбурга м.Інсбург, Аустрія

Оксана Волод

Медичний центр Сідарс-Сінай

м.Лос-Анджелес, Каліфорнія, США

\section{Павло Содомора}

Львівський національний медичний університет імені Данила Галицького, м.Львів, Україна

\section{Роман Гладишевський}

Львівський національний університет імені Івана Франка, м.Львів, Україна

\section{Роман Кушнір}

Голова Наукового товариства імені Шевченка м.Львів, Україна

Ронні Фасс

Медичний центр Клінвленд м.Клівленд, США

\section{Ростислав Білий}

Львівський національний медичний університет імені Данила Галицького, м.Львів, Україна

Ростислав Стойка

Інститут клітинної біології НАН України м.Львів, Україна

\section{Шандор Сабо}

Американський університет наук про здоров'я м.Каліфорнія, США

\section{Сергій Пасічник}

Львівський національний медичний університет імені Данила Галицького, м.Львів, Україна 
Праці НТШ Медичні науки

2020, Том 62, № 2 ISSN 2708-8634 (print)

Від редактора

\section{Serhiy Souchelnytskyi}

Qatar University Doha, Qatar

Svitlana Zubchenko

Danylo Halytsky Lviv National Medical University Lviv, Ukraine

Taras Gutor

Danylo Halytsky Lviv National Medical University Lviv, Ukraine

Taras Zakharkiv

Danylo Halytsky Lviv National Medical University Lviv, Ukraine

Tetyana Nehrych

Danylo Halytsky Lviv National Medical University Lviv, Ukraine

Uliana Pidvalna

Danylo Halytsky Lviv National Medical University Lviv, Ukraine

Ulyana Telishevska

Danylo Halytsky Lviv National Medical University Lviv, Ukraine

Valentyna Chopyak

Danylo Halytsky Lviv National Medical University Lviv, Ukraine

Vassyl Lonchyna

University of Chicago Pritzker School of Medicine Chicago, United States

Vasyl Kovalyshyn

(Danylo Halytsky Lviv National Medical

University, Lviv, Ukraine)

\section{Volodymyr Vovk}

Danylo Halytsky Lviv National Medical University Lviv, Ukraine

Yaroslav Shparyk

Lviv State Oncologic Regional Treatment and Diagnostic Center, Chemotherapy Department Lviv, Ukraine Yulian Kyyak

Danylo Halytsky Lviv National Medical University Lviv, Ukraine

Yurij Ivaniv

Danylo Halytsky Lviv National Medical University Lviv, Ukraine

\section{Zoryana Masna}

Danylo Halytsky Lviv National Medical University Lviv, Ukraine
Proc Shevchenko Sci Soc Med Sci www.mspsss.org.ua ISSN 2708-8642 (online) 2020, Vol. 62,

\author{
Сергій Сушельницький \\ Катарський університет м.Доха, Катар \\ Світлана зубченко
}

Львівський національний медичний університет імені Данила Галицького, м.Львів, Україна

\section{Тарас Гутор}

Львівський національний медичний університет імені Данила Галицького, м.Львів, Україна

Тарас Захарків

Львівський національний медичний університет імені Данила Галицького, м.Львів, Україна

\section{Тетяна Негрич}

Львівський національний медичний університет імені Данила Галицького, м.Львів, Україна

\section{Уляна Підвальна}

Львівський національний медичний університет імені Данила Галицького, м.Львів, Україна

\section{Уляна Телішевська}

Львівський національний медичний університет імені Данила Галицького, м.Львів, Україна

\section{Валентина Чопяк}

Львівський національний медичний університет імені Данила Галицького, м.Львів, Україна

Василь Лончина

Чиказький університет медицини Притцкера м.Чикаго, США

\section{Василь Ковалишин}

(Львівський національний медичний університет імені Данила Галицького, Львів, Україна)

\section{Володимир Вовк}

Львівський національний медичний університет імені Данила Галицького, м.Львів, Україна

\section{Ярослав Шпарик}

Львівський державний онкологічний лікувально-діагностичний центр, відділення хіміотерапії м.Львів, Україна

\section{юліан Кияк}

Львівський національний медичний університет імені Данила Галицького, м.Львів, Україна

\section{Юрій Іванів}

Львівський національний медичний університет імені Данила Галицького, м.Львів, Україна

\section{Зоряна Масна}

Львівський національний медичний університет імені Данила Галицького, м.Львів, Україна

\section{Література / References}

1. Brunner RJ. The language of the doctor and the patient. Proc Shevchenko Sci Soc Med Sci [Internet]. 2018Dec.28 [cited 2020Nov.16];54(2):16-5. Available from: https://mspsss.org.ua/index.php/ journal/article/view/152

2. Furtak $A$, Haun $H$, Bidiuk D. Rare late complications of acute pancreatitis among coloured population 
in africa (clinical case description). Proc Shevchenko Sci Soc Med Sci [Internet]. $2020 \mathrm{Feb.24}$ [cited 2020Nov.16];57(2). Available from: https://mspsss.org.ua/index.php/journal/article/view/230

3. Jaskiw GE. Posttraumatic stress disorder - the neuroscientific basis of evidence-based treatments. Proc Shevchenko Sci Soc Med Sci [Internet]. 2017Dec.20 [cited 2020Nov.16];50(2):23-. Available from: https://mspsss.org.ua/index.php/journal/article/view/103

4. Mahmood A, Lawati A. Renal oncocytoma management in advance renal failure. A case based review. Proc Shevchenko Sci Soc Med Sci [Internet]. 2020Apr.14 [cited 2020Nov.16];59(1). Available from: https://mspsss.org.ua/index.php/journal/article/view/262

5. Nowak A. Is congenital adrenal hyperplasia due to 21 - hydroxylase deficiency deceptive disease? Management and differentiation of syndrome in adults. Proc Shevchenko Sci Soc Med Sci [Internet]. 2017Dec.20 [cited 2020Nov.16];50(2):48-4. Available from: https://mspsss.org.ua/index.php/journal/article/view/105

6. Sandhu DS, Fass R. Stress and gastroesophageal reflux disease. Proc Shevchenko Sci Soc Med Sci [Internet]. 2018Dec.28 [cited 2020Nov.16];54(2):10-5. Available from: https://mspsss.org.ua/ index.php/journal/article/view/150

7. Souchelnytskyi N, Kost A, Souchelnytskyi S. Cell-based diagnostic of bronchial carcinoma: Case study of a diagnostic value of tests of circulating tumor cells and organoid culture. Proc Shevchenko Sci Soc Med Sci [Internet]. 2020Apr.14 [cited 2020Nov.16];59(1). Available from: https://mspsss.org.ua/index. php/journal/article/view/267

8. Szabo S. COVID-19: New disease and chaos with panic, associated with stress. Proc Shevchenko Sci Soc Med Sci [Internet]. 2020Apr.15 [cited 2020Nov.16];59(1). Available from: https://mspsss.org. ua/index.php/journal/article/view/281

9. Forero, D.A., Lopez-Leon, S. \& Perry, G. A brief guide to the science and art of writing manuscripts in biomedicine. J Transl Med 18, 425 (2020). https://doi.org/10.1186/s12967-020-02596-2

10. Ghasemi A, Bahadoran Z, Mirmiran P, Hosseinpanah F, Shiva N, Zadeh-Vakili A. The principles of biomedical scientific writing: Discussion. International journal of endocrinology and metabolism. $2019 \mathrm{Jul} ; 17(3)$.

11. Eaton SE, Stoesz BM, Thacker EJ, Miron JB. Methodological decisions in undertaking academic integrity policy analysis: Considerations for future research. Canadian Perspectives on Academic Integrity. 2020 Jun $5 ; 3(1): 83-91$. 